\title{
The summer of hydrogen sulfide: highlights from two international conferences
}

\author{
John W Calvert
}

\begin{abstract}
A great deal of interest has been paid recently to the hydrogen sulfide, the newest member of the gasotransmitter family. With the growing interest in the biology of $\mathrm{H}_{2} \mathrm{~S}$, the need for meetings and conferences dedicated solely to the field of $\mathrm{H}_{2} \mathrm{~S}$ has also grown. In 2009, scientist from around the world met in Shanghai, China for the first time to discuss the physiological relevance of $\mathrm{H}_{2} \mathrm{~S}$. In 2012, two conferences were organized to bring scientists, clinicians, and industry representatives together to discuss the latest breakthroughs concerning the emergent field of $\mathrm{H}_{2} \mathrm{~S}$. The following is a summary report of The First European Conference on the Biology of Hydrogen Sulfide and the Second International Conference on Hydrogen Sulfide Biology and Medicine.
\end{abstract}

Keywords: Gasotransmitter, Hydrogen sulfide, Nitric oxide, Carbon monoxide

\section{Introduction}

Gasotransmitters are small, labile, endogenously-produced gaseous molecules that play important roles in cellular signaling [1]. Hydrogen sulfide $\left(\mathrm{H}_{2} \mathrm{~S}\right)$ is the newest member of the gasotransmitter family. Historically, it was considered to be highly toxic and hazardous to the environment [2]. However, $\mathrm{H}_{2} \mathrm{~S}$ has recently emerged as a critical physiological gaseous signaling molecule that is produced enzymatically in all mammalian species at low micromolar levels via the action of cysteine metabolic enzymes: cystathionine- $\gamma$-lyase (CSE), cystathionine- $\beta$ -synthase (CBS), and 3-mercaptopyruvate sulfutransferase (3-MST) [3]. Because of this discovery, the biological and physiological role of $\mathrm{H}_{2} \mathrm{~S}$ has been re-evaluated. As such, an extensive amount of work has been conducted over the last several decades and has led to the discovery that $\mathrm{H}_{2} \mathrm{~S}$ possesses a number of physiological actions.

In 1989, while investigation the effects of acute $\mathrm{H}_{2} \mathrm{~S}$ poisoning in the brain, Warenycia et al. [4] first reported that $\mathrm{H}_{2} \mathrm{~S}$ was produced endogenously. Soon after this discovery, other investigators started to take a closer look at $\mathrm{H}_{2} \mathrm{~S}$ and evidence soon emerged to demonstrate its physiological importance. For instance, Skrajny et al. [5] found increased levels of serotonin and reduced levels of norepinephrine in the frontal cortex of a rat

Correspondence: jcalver@emory.edu

Department of Surgery, Division of Cardiothoracic Surgery, Carlyle Fraser Heart Center, Emory University of Medicine, Atlanta, GA 30308, USA when chronically exposed to $20 \mathrm{ppm}$ of $\mathrm{H}_{2} \mathrm{~S}$ and in 1996, Abe et al. [6] suggested that $\mathrm{H}_{2} \mathrm{~S}$ was an endogenous neuromodulator, as they showed that physiological concentrations of $\mathrm{H}_{2} \mathrm{~S}$ enhanced $\mathrm{N}$-methyl-D-aspartate (NMDA) receptor-mediated responses and aided in the induction of hippocampal long-term potentiation. Shortly after, Hosoki et al. [7] reported that an $\mathrm{H}_{2} \mathrm{~S}$-producing enzyme was present in the vasculature and proposed that $\mathrm{H}_{2} \mathrm{~S}$ may be an endogenous smooth muscle relaxant. Since these initial offerings, studies have begun to characterize its biological profile and therapeutic potential. Over the last several years, a great amount of work by investigators all over the world have led to the suggestion that $\mathrm{H}_{2} \mathrm{~S}$ is a powerful signaling molecule with a diverse physiological profile. Moreover, because of its physiological actions, $\mathrm{H}_{2} \mathrm{~S}$ has been reported to protect the heart, brain, liver, kidney, and lungs against a variety of pathological stimuli, including ischemia/reperfusion (I/R) injury [8-17].

With the growing interest in the biology of $\mathrm{H}_{2} \mathrm{~S}$, the need for meetings and conferences dedicated solely to the field of $\mathrm{H}_{2} \mathrm{~S}$ has also grown. In 2009, scientists from around the world met in Shanghai, China for the first time to discuss the physiological relevance of $\mathrm{H}_{2} \mathrm{~S}$. In 2012, two conferences were organized to bring scientists, clinicians, and industry representatives together to discuss the latest breakthroughs concerning the emergent 
field of $\mathrm{H}_{2} \mathrm{~S}$. The following is a summary of the highlights from those two meetings.

\section{First European conference on the biology of hydrogen sulfide}

The First European Conference on the Biology of Hydrogen Sulfide was held at Smolenice Castle on the outskirts of Bratislava, Slovakia from June 15 to 18, 2012. The Institute of Molecular Physiology and Genetics from the Slovak Academy of Sciences sponsored this conference. Dr Karol Ondrias from the Slovak Academy of Sciences served as the Conference Chairman and Dr Matthew Whiteman from the University of Exeter served as Honorary Chairman and Chairman of the International Advisory Committee. Together with the rest of the members of the International Advisory Committee, Drs Ondrias and Whiteman organized an outstanding scientific program consisting of 12 plenary lectures, 34 short oral presentations, and 15 poster presentations.

The meeting started with a Keynote Lecture delivered by Dr Rui Wang from Lakehead University in Thunder Bay, Ontario, Canada. In his lecture, Dr Wang discussed several recent findings regarding where inside the eukaryotic cell $\mathrm{H}_{2} \mathrm{~S}$ is produced and how this intracellular compartmentalization is realized. He also discussed the functional consequences of $\mathrm{H}_{2} \mathrm{~S}$ production in response to difference stimuli. Dr Wang's lecture was followed by a very nice welcome reception where the attendees were inundated with local Slovakian cuisine.

Day 2 of the conference began with a session focused on the effects of $\mathrm{H}_{2} \mathrm{~S}$ on heart and vascular physiology. Dr Y.Z. Zhu from Fudan University in Shanghai China began the session by detailing recent work on the involvement of $\mathrm{H}_{2} \mathrm{~S}$ in the cardiovascular disorder processes and the prospects of new therapeutic strategies based on the regulation of endogenous $\mathrm{H}_{2} \mathrm{~S}$ production [18]. This session was highlighted by Dr David Lefer from Emory University in Atlanta GA who presented recent work investigating the role of cystathionine gamma lyase derived $\mathrm{H}_{2} \mathrm{~S}$ in the development of pressure-induced heart failure. $\mathrm{He}$ also presented novel and exciting data regarding the effects of oral $\mathrm{H}_{2} \mathrm{~S}$ therapy on preventing cardiac dysfunction following the induction of heart failure.

There is emerging evidence that members of the gasotransmitter family can interact with each other. For instance, $\mathrm{NO}$ and $\mathrm{H}_{2} \mathrm{~S}$ have been suggested to collaborate in regulating vascular homeostasis and vasodilation. Additional evidence suggests that NO can increase CGL activity acutely, and that chronic exposure to $\mathrm{NO}$ up-regulates CGL expression. Moreover, at low concentrations $\mathrm{H}_{2} \mathrm{~S}$ has been shown to enhance the release of NO from vascular endothelium and increase the vasorelaxant effect of the NO donor sodium nitroprusside [19]. Furthermore, a 10 fold increase in $\mathrm{H}_{2} \mathrm{~S}$ levels have been reported with administration of NO donors [20], suggesting a synergistic relationship between $\mathrm{NO}$ and $\mathrm{H}_{2} \mathrm{~S}$. Dr Andreas Papapetropoulos from the University of Patras in Greece detailed very exciting and new results that further demonstrate the interdependence of the gasotransmitters on each other. Specifically, he provided the audience with compelling evidence that angiogenesis and vasodilatation require the simultaneous production of $\mathrm{H}_{2} \mathrm{~S}$ and $\mathrm{NO}$, suggesting that both are mutually required for the control of vascular function [21].

Day 2 concluded with two afternoon sessions. The first session focused on the ability of $\mathrm{H}_{2} \mathrm{~S}$ to regulate respiratory and gastrointestinal function. Dr John Wallace from McMaster University in Hamilton, Ontario, Canada discussed his group's latest findings regarding the ability of novel $\mathrm{H}_{2} \mathrm{~S}$ releasing anti-inflammatory drugs to alleviate the development of gastrointestinal (GI) ulcers [22]. The last session of Day 2 focused on $\mathrm{H}_{2} \mathrm{~S}$ donors and was highlighted by Dr Mathew Whiteman's presentation on the use of $\mathrm{H}_{2} \mathrm{~S}$ donors to treat inflammatory joint disease.

Dr Csabo Szabo from the University of Texas Medical Branch in Galvaston, TX opened the morning session on Day 3 by discussing the role of $\mathrm{H}_{2} \mathrm{~S}$ deficiency in the pathogenesis of diabetic vascular complications. In his presentation he provided the audience with compelling data suggesting that $\mathrm{H}_{2} \mathrm{~S}$ deficiency is emerging as a significant pathogenic mechanism in diabetic complication, while $\mathrm{H}_{2} \mathrm{~S}$ supplementation has the potential to be a novel therapeutic approach [23]. The session on $\mathrm{H}_{2} \mathrm{~S}$ and diabetes was followed by a session regarding the interaction of $\mathrm{H}_{2} \mathrm{~S}$ with the mitochondria. This session was highlighted by Dr Katalin Modis' (University of Texas Medical Branch in Galvaston, TX) presentation detailed her exciting work demonstrating that $\mathrm{H}_{2} \mathrm{~S}$ has a physiological role as a positive modulator of mitochondrial electron transport that is dependent on a basal activity of the Krebs cycle [24].

In the afternoon, Dr Hideo Kimura from the National Institute of Neuroscience in Tokyo, Japan led off a very interesting and stimulating session on the synthesis of hydrogen sulfide. In his talk, Dr Kimura detailed his group's efforts to identify the endogenous reducing substances (thioredoxin and dihydrolipoic acid) that facilitate the production of $\mathrm{H}_{2} \mathrm{~S}$ from 3-mercaptopyruvate sulfurtransferase [25]. This was followed by a very stimulating presentation from the Ondrias group detailing their work suggesting that $\mathrm{H}_{2} \mathrm{~S}$ induces the release of $\mathrm{NO}$ from nitroso groups. Day 3 ended with a very informative session regarding the interaction of $\mathrm{H}_{2} \mathrm{~S}$ with different ion channels.

The Final Day of the conference ended with several talks discussing the latest findings regarding the role of $\mathrm{H}_{2} \mathrm{~S}$ in the setting of cellular stress and cell proliferation. 
Additionally, awards were handed out at the conclusion of the conference to several young investigators.

\section{The second international conference on $\mathrm{H}_{2} \mathrm{~S}$ biology and medicine}

With the momentum gained at Smolenic Castle in Bratislava, scientists, clinicians, and industry representatives from around the world descended on Atlanta, GA from September 20 - 22, 2012 to attend the Second International Conference on $\mathrm{H}_{2} \mathrm{~S}$ Biology and Medicine. Dr David Lefer from Emory University in Atlanta, GA organized this conference. Together with the rest of the member of the Organizing Committee, Dr Lefer planned a well-balanced scientific program detailing the latest findings concerning the chemistry and biology of $\mathrm{H}_{2} \mathrm{~S}$. The final program consisted of 30 plenary lectures, 4 short oral presentations, and over 75 poster presentations.

Dr Solomon Snyder from Johns Hopkins University in Baltimore, MD delivered the keynote lecture to start the conference. In his lecture, Dr Solomon eloquently discussed his group's efforts to characterize sulfhydration, which is the mechanism by which $\mathrm{H}_{2} \mathrm{~S}$ modifies reactive cysteine residues on targeted proteins. Although analogous to protein nitrosylation, sulfhydration is substantially more prevalent and usually increases the catalytic activity of targeted proteins [26].

Dr Snyder's lecture was followed by several presentations on the biology and chemistry of $\mathrm{H}_{2} \mathrm{~S}$. Highlights from this session included Dr Nicholas Tonk's (Cold Spring Harbor Laboratory) presentation on his recent work detailing of the effects of $\mathrm{H}_{2} \mathrm{~S}$ on the endoplasmic reticulum stress response. Specifically, he presented data demonstrating that $\mathrm{H}_{2} \mathrm{~S}$ reversibly inhibits the activity of protein tyrosine phosphatase $1 \mathrm{~B}$, which promotes the activity of protein kinase-like endoplasmic reticulum (ER) kinase (PERK) during the response to ER stress [27]. With the growing interest in the physiological and biological role of $\mathrm{H}_{2} \mathrm{~S}$, there is a need for better detection methods for $\mathrm{H}_{2} \mathrm{~S}$ levels and signaling. This was a constant point of discussion throughout the meeting. As such, Dr Ming Xian's (Washington State University in Pullman, WA) presentation on new chemical tools for $\mathrm{H}_{2} \mathrm{~S}$ research was of particular interest. In his talk, Dr Xian provided evidence that newly developed fluorescent probes provide good selectivity and sensitivity for $\mathrm{H}_{2} \mathrm{~S}$ [28].

The afternoon session of Day 1 was dedicated to discussion on the role that $\mathrm{H}_{2} \mathrm{~S}$ plays in the development and treatment of cardiovascular disease. Dr Frank Sellke from Brown University in Providence, RI led off this session by discussing his labs previous work investigating the impact of $\mathrm{H}_{2} \mathrm{~S}$ on myocardium in the setting of cold crystalloid cardioplegia and cardiopulmonary bypass [29]. In his talk, Dr Sellke provided compelling evidence that treatment with $\mathrm{H}_{2} \mathrm{~S}$ offered myocardial protection via attenuation of caspase-independent apoptosis and autophagy in a porcine model of cardiopulmonary bypass. Later in this session, Dr Suresh Tyagi from the University of Louisville in Louisville, $\mathrm{KY}$ summarized his groups' findings regarding the effects of $\mathrm{H}_{2} \mathrm{~S}$ on cardiovascular remodeling in response to heart failure [30]. Day 1 concluded with a reception and presentation of posters.

Day 2 of the conference featured three sessions. The first session of the morning was focused on $\mathrm{H}_{2} \mathrm{~S}$ and the vasculature. Dr Rui Wang from Lakehead University in Thunder Bay, Ontario, Canada started the session with a nice introduction to the effects of $\mathrm{H}_{2} \mathrm{~S}$ on the vascular endothelium. This was followed by Dr Guiseppe Cirino's (University of Naples, Naples, Italy) presentation on $\mathrm{H}_{2} \mathrm{~S}$ as an endogenous inhibitor of phosphodiesterases and how this affects vascular tone.

The second session of Day 2 was focused on the $\mathrm{H}_{2} \mathrm{~S}$ and gastrointestinal diseases. Presentations in this session from Drs. John Wallace (McMaster University in Hamilton, Ontario, Canada), Mauro Perretti (Queen Mary University), Nathalie Vergnolle (INSERM), and Andre Buret (University of Calgary) detailed the latest findings regarding the role of $\mathrm{H}_{2} \mathrm{~S}$ in the resolution and repair of the GI tract and detailed the latest developments in use of novel $\mathrm{H}_{2} \mathrm{~S}$ releasing drugs to treat GI disorders.

The final session of Day 2 was concentrated on the role of $\mathrm{H}_{2} \mathrm{~S}$ in shock and sepsis. This session began with a very informative presentation by Dr Konstantin Shatalin (New York University) in which he discussed the role $\mathrm{H}_{2} \mathrm{~S}$ plays in mediating bacteria defense against antibiotics [31]. Specifically, Dr Shatalin provided evidence that inactivation of putative cystathionine $\beta$ synthase, cystathionine $\gamma$-lyase, or 3-mercaptopyruvate sulfurtransferase in Bacillus anthracis, Pseudomonas aeruginosa, Staphylococcus aureus, and Escherichia coli suppresses $\mathrm{H}_{2} \mathrm{~S}$ production, rendering these pathogens highly sensitive to a multitude of antibiotics. Dr Fumito Ichinose from Harvard University in Boston, MA then detailed recent findings from his lab in which they demonstrated that inhaled $\mathrm{H}_{2} \mathrm{~S}$ prevents inflammation and improves survival in the setting of endotoxemia by altering sulfide metabolism in mice [32].

The final day of the conference began with presentations selected from submitted abstracts. This forum gave deserving young investigators and trainees the opportunity to present their latest findings in a more formal setting. This session was followed by a second session on $\mathrm{H}_{2} \mathrm{~S}$ and the vasculature. Dr Christopher Peers from the University of Leeds in Leeds, England highlighted this session with his presentation on the regulation of ion channels by $\mathrm{H}_{2} \mathrm{~S}$. Dr Chris Kevil from LSU-Health Sciences Center in Shreveport, LA delivered 
the last talk of the conference detailing his groups latest work on the actions of $\mathrm{H}_{2} \mathrm{~S}$ in the setting of high limb ischemia.

\section{Summary and comments}

In summary, the First European Conference on the Biology of $\mathrm{H}_{2} \mathrm{~S}$ and the Second International Conference on $\mathrm{H}_{2} \mathrm{~S}$ Biology and Medicine were both a tremendous successes. Each conference provided an excellent platform for the presentation and discussion of the latest findings regarding the biology and chemistry of $\mathrm{H}_{2} \mathrm{~S}$. In addition, both of these conferences served as a reminder that that is still so much about $\mathrm{H}_{2} \mathrm{~S}$ that we do not know. In this regard, a number of important issues/questions were raised at each conference that will certainly drive research in the years to come. These include (1) the need to develop more sensitive ways to measure $\mathrm{H}_{2} \mathrm{~S}$, (2) the need to develop new drugs or delivery mechanisms to deliver sustained levels of $\mathrm{H}_{2} \mathrm{~S}$, and (3) the need to understand the molecular targets of $\mathrm{H}_{2} \mathrm{~S}$ and the manner in which $\mathrm{H}_{2} \mathrm{~S}$ modifies these cellular targets.

It was recently announced that there will be a Second European Conference in Exeter England from September 8-11, 2013. Dr Matthew Whiteman will serve as the Organizer. In addition, Dr Hideo Kimura will serve as the organizer for the next International $\mathrm{H}_{2} \mathrm{~S}$ meeting. $\mathrm{He}$ announced at the conclusion of the Atlanta meeting that the next International conference on $\mathrm{H}_{2} \mathrm{~S}$ will be held in Japan in 2014. For more information about this conference and other conferences related to $\mathrm{H}_{2} \mathrm{~S}$ please log on to the European Network on Gasotransmitters website for the latest news and developments (http://www. gasotransmitters.eu/).

\section{Competing interest}

All authors declare that they have no competing interest.

\section{Disclosures}

John Calvert served as Vice Chairman of the Organizing committee for the Second International Conference on $\mathrm{H}_{2} \mathrm{~S}$ Biology and Medicine.

\section{Sources of funding \\ Supported by grants from the American Diabetes Association (7-09-BS-26) and the National Institutes of Health National Heart Lung and Blood Institute (NHLBI) (5R01HL098481-03) to J.W.C. This work was also supported by funding from the Carlyle Fraser Heart Center (CFHC) of Emory University Hospital Midtown.}

Received: 23 December 2012 Accepted: 15 February 2013 Published: 25 February 2013

\section{References}

1. Nicholson CK, Calvert JW: Hydrogen sulfide and ischemia-reperfusion injury. Pharmacol Res 2010, 62:289-297.

2. Ramazzini B: Diseases of Workers - De Morbis Artificum Diatriba - 1713. New York: C. Hafner Publishing Co Inc; 1964.

3. Li L, Rose P, Moore PK: Hydrogen sulfide and cell signaling. Annu Rev Pharmacol Toxicol 2011, 51:169-187.

4. Warenycia MW, Goodwin LR, Benishin CG, Reiffenstein RJ, Francom DM, Taylor JD, Dieken FP: Acute hydrogen sulfide poisoning. Demonstration of selective uptake of sulfide by the brainstem by measurement of brain sulfide levels. Biochem Pharmacol 1989, 38:973-981.

5. Skrajny B, Hannah RS, Roth SH: Low concentrations of hydrogen sulphide alter monoamine levels in the developing rat central nervous system. Can J Physiol Pharmacol 1992, 70:1515-1518.

6. Abe $\mathrm{K}$, Kimura $\mathrm{H}$ : The possible role of hydrogen sulfide as an endogenous neuromodulator. J Neurosci 1996, 16:1066-1071.

7. Hosoki R, Matsuki N, Kimura H: The possible role of hydrogen sulfide as an endogenous smooth muscle relaxant in synergy with nitric oxide. Biochem Biophys Res Commun 1997, 237:527-531.

8. Bian JS, Yong QC, Pan TT, Feng ZN, Ali MY, Zhou S, Moore PK: Role of hydrogen sulfide in the cardioprotection caused by ischemic preconditioning in the rat heart and cardiac myocytes. J Pharmacol Exp Ther 2006, 316:670-678.

9. Kimura $\mathrm{Y}$, Kimura $\mathrm{H}$ : Hydrogen sulfide protects neurons from oxidative stress. FASEB J 2004, 18:1165-1167.

10. Elrod JW, Calvert JW, Morrison J, Doeller JE, Kraus DW, Tao L, Jiao X, Scalia R, Kiss $L$, Szabo C, et al: Hydrogen sulfide attenuates myocardial ischemiareperfusion injury by preservation of mitochondrial function. Proc Natl Acad Sci U S A 2007, 104:15560-15565.

11. Sivarajah A, McDonald MC, Thiemermann C: The production of hydrogen sulfide limits myocardial ischemia and reperfusion injury and contributes to the cardioprotective effects of preconditioning with endotoxin, but not ischemia in the rat. Shock 2006, 26:154-161.

12. Bliksoen M, Kaljusto ML, Vaage J, Stenslokken KO: Effects of hydrogen sulphide on ischaemia-reperfusion injury and ischaemic preconditioning in the isolated, perfused rat heart. Eur J Cardiothorac Surg 2008, 34:344-349.

13. Florian B, Vintilescu R, Balseanu AT, Buga AM, Grisk O, Walker LC, Kessler C, Popa-Wagner A: Long-term hypothermia reduces infarct volume in aged rats after focal ischemia. Neurosci Lett 2008, 438:180-185.

14. Jha S, Calvert JW, Duranski MR, Ramachandran A, Lefer DJ: Hydrogen sulfide attenuates hepatic ischemia-reperfusion injury: role of antioxidant and antiapoptotic signaling. Am J Physiol Heart Circ Physiol 2008, 295:H801-H806.

15. Tripatara P, Patel NS, Collino M, Gallicchio M, Kieswich J, Castiglia S, Benetti E, Stewart KN, Brown PA, Yaqoob MM, et al: Generation of endogenous hydrogen sulfide by cystathionine gamma-lyase limits renal ischemia/ reperfusion injury and dysfunction. Lab Invest 2008, 88:1038-1048.

16. Xu Z, Prathapasinghe G, Wu N, Hwang SY, Siow YLOK: Ischemiareperfusion reduces cystathionine-beta-synthase-mediated hydrogen sulfide generation in the kidney. Am J Physiol Renal Physiol 2009, 297:F27-F35.

17. Fu Z, Liu X, Geng B, Fang L, Tang C: Hydrogen sulfide protects rat lung from ischemia-reperfusion injury. Life Sci 2008, 82:1196-1202.

18. Gu X, Zhu YZ: Therapeutic applications of organosulfur compounds as novel hydrogen sulfide donors and/or mediators. Expert Rev Clin Pharmacol 2011, 4:123-133.

19. Zhao W, Zhang J, Lu Y, Wang R: The vasorelaxant effect of $H(2) S$ as a novel endogenous gaseous K(ATP) channel opener. EMBO J 2001, 20:6008-6016.

20. Eto $\mathrm{K}$, Kimura $\mathrm{H}$ : The production of hydrogen sulfide is regulated by testosterone and S-adenosyl-L-methionine in mouse brain. J Neurochem 2002, 93:80-86.

21. Coletta C, Papapetropoulos A, Erdelyi K, Olah G, Modis K, Panopoulos P, Asimakopoulou A, Gero D, Sharina I, Martin E, Szabo C: Hydrogen sulfide and nitric oxide are mutually dependent in the regulation of angiogenesis and endothelium-dependent vasorelaxation. Proc Natl Acad Sci U S A 2012, 109:9161-9166.

22. Wallace JL: Hydrogen sulfide: a rescue molecule for mucosal defence and repair. Dig Dis Sci 2012, 57:1432-1434.

23. Szabo C: Roles of hydrogen sulfide in the pathogenesis of diabetes mellitus and its complications. Antioxid Redox Signal 2012, 17:68-80.

24. Modis K, Coletta C, Erdelyi K, Papapetropoulos A, Szabo C: Intramitochondrial hydrogen sulfide production by 3-mercaptopyruvate sulfurtransferase maintains mitochondrial electron flow and supports cellular bioenergetics. Faseb J 2012, 27:601-611.

25. Mikami Y, Shibuya N, Kimura Y, Nagahara N, Ogasawara Y, Kimura H: Thioredoxin and dihydrolipoic acid are required for 3-mercaptopyruvate sulfurtransferase to produce hydrogen sulfide. Biochem J 2011, 439:479-485. 
26. Ambrus GG, Al-Moyed H, Chaieb L, Sarp L, Antal A, Paulus W: The fadein-short stimulation-fade out approach to sham tDCS-reliable at $1 \mathrm{~mA}$ for naive and experienced subjects, but not investigators. Brain Stimul 2012, 5:499-504.

27. Krishnan N, Fu C, Pappin DJ, Tonks NK: $\mathrm{H}_{2} \mathrm{~S}$-Induced sulfhydration of the phosphatase PTP1B and its role in the endoplasmic reticulum stress response. Sci Signal 2011, 4:ra86.

28. Liu C, Peng B, Li S, Park CM, Whorton AR, Xian M: Reaction based fluorescent probes for hydrogen sulfide. Org Lett 2012, 14:2184-2187.

29. Osipov RM, Robich MP, Feng J, Chan V, Clements RT, Deyo RJ, Szabo C, Sellke FW: Effect of hydrogen sulfide on myocardial protection in the setting of cardioplegia and cardiopulmonary bypass. Interact Cardiovasc Thorac Surg 2010, 10:506-512.

30. Givvimani S, Munjal C, Gargoum R, Sen U, Tyagi N, Vacek JC, Tyagi SC: Hydrogen sulfide mitigates transition from compensatory hypertrophy to heart failure. J Appl Physiol 2011, 110:1093-1100.

31. Shatalin $\mathrm{K}$, Shatalina E, Mironov A, Nudler E: $\mathrm{H}_{2} \mathrm{~S}$ : a universal defense against antibiotics in bacteria. Science 2011, 334:986-990.

32. Tokuda K, Kida K, Marutani E, Crimi E, Bougaki M, Khatri A, Kimura H, Ichinose F: Inhaled hydrogen sulfide prevents endotoxin-induced systemic inflammation and improves survival by altering sulfide metabolism in mice. Antioxid Redox Signal 2012, 17:11-21.

doi:10.1186/2045-9912-3-5

Cite this article as: Calvert: The summer of hydrogen sulfide: highlights from two international conferences. Medical Gas Research 2013 3:5.

\section{Submit your next manuscript to BioMed Central and take full advantage of:}

- Convenient online submission

- Thorough peer review

- No space constraints or color figure charges

- Immediate publication on acceptance

- Inclusion in PubMed, CAS, Scopus and Google Scholar

- Research which is freely available for redistribution 